\title{
NOTE
}

\section{Fate and possible effects of excessive sperm released during spawning}

\author{
I. E. D. Dundas
}

Department of Microbiology and Plant Physiology, University of Bergen, Allegaten 70, N-5000 Bergen, Norway

\begin{abstract}
A great number of marine animals rely on communal spawning for procreation. Male gonad material released during spawning represents a significant proportion of the total biomass of the population. Only insignificant proportions of this material are functional in fertilization, the remainder represents a nutritional input to phagotrophic and osmotrophic microbial food webs, allowing increased productivity at this level of the ecosystem. Degradation of male gonad material also results in increased nutrient availability for eventual phytoplankton productivity. The extent to which this might influence survival of fish larvae is discussed.
\end{abstract}

A great number of marine animals rely on sexual mechanisms involving external fertilization, spawning, for procreation. Spawning entails the release into the water of massive amounts of male gonad material, only a minimal fraction of which is directly involved in fertilization. Male gonads comprise from some $20 \%$ (herring and mackerel) to about 10\% (codfish and haddock) of live spawn-ripe individual fish weight. Accordingly, material corresponding to some $5 \%$ to $10 \%$ of spawning fish biomass may be released into the water as sperm and sperm fluid during spawning. During spawning of herring under natural conditions the water may become visibly discolored, due to the massive release of sperm (Hourston \& Rosenthal 1976).

Little work seems to have been done to investigate the fate of surplus sperm material. Microscope observations in our laboratory show that fresh cod sperm cells quickly lyse and release sperm head material on exposure to sea water. Less than $10 \%$ of the sperm cells maintain structural integrity $10 \mathrm{~min}$ after exposure.

Diluting $1 \mathrm{ml}$ of freshly stripped codfish milt into $1 \mathrm{l}$ of sea water supports massive bacterial growth. Microscope observation shows that bacteria also rapidly colonize cellular debris remaining after sperm cell lysis (author's unpubl. results).

Influence of spawning location and timing on recruitment. Survival of cod larvae is dependent on food availability at a critical stage when the yolk sac just has been resorbed (Solberg \& Tilseth 1984). Already in 1914 Hjort (1914) suggested that cod stock recruitment depended on the degree of temporal matching between peak spawning and peak production of adequate food for larvae. It has been shown that the minimum food requirement of cod larvae at the critical stage is higher than the average food availability in the environment (Solberg \& Tilseth 1984). Vlymen (1977) suggested that larval survival is dependent on a spatial matching of larvae and patches of water with higher than average densities of larval prey. It has been proposed that recruitment is enhanced if fertilized eggs and emerging larvae of herring (Iles \& Sinclair 1982) and haddock (Smith \& Morse 1985) remain in a restricted water mass such as that represented by the rather stable gyre on Georges Bank off New England. This gyre has an extension of about $10,000 \mathrm{~km}^{2}$ (Iles \& Sinclair 1982) with a depth of some $40 \mathrm{~m}$ corresponding to a volume of $4 \times 10^{11} \mathrm{~m}^{3}$. The water in the gyre has a long volume replenishing time on the order of months (Hopkins \& Garfield 1981). Iles \& Sinclair (1982) also suggested that in general herring stock sizes are limited by the size of the larval retention areas available for the spawning populations. Serebryakov et al. (1984) argue that the magnitude of the spawning biomass is a major factor deciding recruitment efficiency of Arcto-Norwegian cod.

The 2 general views, that the retention of larvae in discrete water masses is important for recruitment, and that the size of spawning biomass is important for recruitment, may be reconciled if both mechanisms increase the probability of a temporal and spatial match between the fish larvae and their food in the critical survival period. Such would be the case if excess male gonad products released during spawning were partially instrumental in triggering microbial productivity and increasing the availability of ade- 
quate larval prey at the critical stage. Any mechanism increasing food availability at the critical stage, even if only marginally, may have significant effects on population recruitment.

Effect of excess spawning materials on microbial populations. The normal microbial food web in natural sea water includes bacterial populations with densities of $1 \times 10^{5}$ to $1 \times 10^{6}$ cells $\mathrm{ml}^{-1}$ utilizing both soluble and particulate material as nutrient, microbial populations of microflagellates with densities of about $1 \times 10^{3}$ cells $\mathrm{ml}^{-1}$ utilizing particulate material in the proper size range (including bacteria) as nutrient, and populations of larger phagotrophic microorganisms (Azam et al. 1983)

Fish sperm and sperm debris after lysis represent a nutritional input to phagotrophic microbial populations of flagellates and ciliates. Because cod sperm tend to lyse and disintegrate shortly after release, much of the soluble content of sperm, largely nucleic acid (DNA) and nucleohistones, represents a nutritional input to the normal bacterial flora in the water mass. The release of large amounts of 'excessive' male gonad products during spawning would accordingly increase productivity in microplankton food webs able to utilize and degrade the released particulate and soluble material.

It has been suggested that gonadal products may significantly increase secondary productivity when herring spawn in the Strait of Georgia (Hay \& Fulton 1983). Nucleic acid and nucleohistones are so rich in organic nitrogen and phosphate that any organism utilizing such materials as nutrients must excrete large amounts of the ingested material as inorganic or organic nitrogen and phosphate. The degradation products from sperm material may later become available for primary productivity, possibly influencing timing, productivity and species composition of phytoplankton blooms. Such effects would depend on hydrologic conditions, transporting, dispersing and diluting sperm material and its degradation products.

Microbial degradation of excess male gonad material. Each year between the middle of March and the middle of April spawn-ripe codfish congregate off Lofoten islands in Norway. The size of the spawning population has been estimated to be 80 million individuals in 1982 (Nakken 1984), roughly corresponding to a biomass of some 320 million $\mathrm{kg}$, assuming an average weight of $4 \mathrm{~kg}$. Assuming a $50 \%$ male population and a male gonad weight amounting to $10 \%$ of body weight, rougly i6 million $\mathrm{kg}$ of male cod gonad material may be released during spawning. Cod male gonads have a dry matter content of about $16 \%$ of wet weight (Boge \& Braekkan 1974) while freshly stripped milt has a dry weight content as low as $8.1 \%$ with a phosphorus content of $2.4 \%$, a nitrogen content of
$12.8 \%$ and a carbon content of $47 \%$ (author's unpubl. results).

If 1.6 million $\mathrm{kg}$ dry weight male gonad material is released, 38 metric tons of phosphorus, 205 metric tons of nitrogen and 752 metric tons of carbon are made available as soluble and particulate organic material. This material would directly increase secondary productivity in the microbial food web while primary productivity would be enhanced only after degradation of the released material. The degraded material could increase phosphate concentration by some 0.1 $\mu \mathrm{g}$-at $\mathrm{l}^{-1}$ and the bound nitrogen concentration by more than $1.0 \mu \mathrm{g}$-at $\mathrm{l}^{-1}$ in a water mass of $1.2 \times 10^{13} 1$, corresponding to a water column $50 \mathrm{~m}$ deep with an extension of $240 \mathrm{~km}^{2}$.

The above calculations refer only to the spawning biomass of codfish off Lofoten. In 1982 some 90 million individuals of Arcto-Norwegian codfish spawned at selected sites south and north of Lofoten (Nakken 1984). Simultaneous massive spawning by large populations of Norway pout in the same area also contributed to increased availabilty of nutrients for secondary and primary production.

Due to the permanence of the water mass on Georges Bank, all the various fish populations spawning on the bank will directly contribute in increasing nutrient concentrations in the water mass where their eggs will hatch and their larvae forage. In this case the same water mass functions as a spawning and as a nursery area. The more complex hydrological conditions off the Norwegian coast makes it difficult to infer to what extent excess sperm degradation products could affect conditions in the nursery areas. Relatively stable gyres do seem to occur also in this area (Sundby 1983), affecting the concentration patterns of fertilized eggs and larvae.

Table 1 lists some major actual and potential spawning populations of fish and gives the corresponding amounts of released male gonad material. The potential primary productivity calculated on the basis of released nitrogen is larger than the immediately available carbon from released sperm, reflecting the much higher N/C ratio of sperm material compared to phytoplankton biomass. Table 1 also attempts to compute the water masses in which the produced male gonad material could increase the concentration of phosphate and bound nitrogen by respectively 1 and $10 \mu \mathrm{g}$-at $\mathrm{l}^{-1}$. While such concentrations only correspond to a doubling of the normal concentrations in deeper water, it must be reemphasized that even small effects, slightly enhancing the probability that larvae encounter a patch of suitable prey, may be significant for recruitment.

The time required for hatching of codfish eggs, some 2 to $3 w k_{1}$ depending on the temperature (Solberg \& 
Nakken, O. (1984). Acoustic estimates of spawning cod in the Lofoten area in 1982 and 1983. In: Godo, O. R., Tilseth, S. (ed.) The proceedings of the Soviet-Norwegian symposium on reproduction and recruitment of Arctic cod. Institute of Marine Research, Bergen, Norway, p. 99-115

Serebryakov, V. P., Borisov, V. M., Aldonov, V K. (1984). Population fecundity and abundance of year-classes of the Arcto-Norwegian cod. In: Godo, O. R., Tilseth. S. (ed.) The Proceedings of the Soviet-Norwegian symposium on reproduction and recruitment of Arctic cod. Institute of Marine Research, Bergen, Norway, p. 139-156

Smith, W. G., Morse, W. W. (1985), Retention of larval haddock Melanogrammus aeglefinus in the Georges Bank region, a gyre-influenced spawning area. Mar. Ecol. Prog. Ser. 24: $1-13$

Solberg, T., Tilseth, S. (1984). Growth, energy consumption and prey density requirements in first feeding larvae of cod (Gadus morhuae L.). Flodevigen rapportser 1: 145-166 Souci, S. W., Fachmann, W. Kraut, H. (1962). Die Zusammensetzung der Lebensmittel. Wissenschaftliche Verlagsgesellschaft, Stuttgart

Sundby, S. (1983). Influence of bottom tophography on the circulation at the continental shelf of northern Norway. Norwegian Fisheries Research Institute. Report No. FO 8308, p. 1-30 (Mimeo)

Vlymen, W. J., III. (1977). A mathematical model of the relationship between larval anchovy (Engraulis mordax) growth, prey microdistribution, and larval behaviour. Environ. Biol. Fish. 2: 211-233

Accepted for printing on January 14, 1986 